\title{
Sciendo
}

RESEARCH PAPERS FACULTY OF MATERIALS

SCIENCE AND TECHNOLOGY IN TRNAVA

SLOVAK UNIVERSITY OF TECHNOLOGY

IN BRATISLAVA

2021, Volume 29, Number 48

DOI 10.2478/rput-2021-0017

\section{ELECTROCHEMICAL RECOVERY OF SILVER USING A SIMPLE CELL}

\author{
Igor WACHTER $^{1}$, Tomáš ŠTEFKO ${ }^{1}$ \\ ${ }^{1}$ SLOVAK UNIVERSITY OF TECHNOLOGY IN BRATISLAVA \\ FACULTY OF MATERIALS SCIENCE AND TECHNOLOGY IN TRNAVA \\ INSTITUTE OF INTEGRATED SAFETY \\ Ulica JÁna BotTu 2781/25, 91724 TRNAVA, SlOVAK REPUbliC \\ e-mail: igor.wachter@stuba.sk, tomas.stefko@stuba.sk \\ Received 27 April 2021, Accepted 10 June 2021, Published 20 July 2021
}

\begin{abstract}
The amount of generated e-waste during the last decades has been steadily raising to the point at which it is highly desirable to obtain the precious metals by recycling the e-waste without the need of exploiting the environment. The rapid development of technology, steep growth of modern facilities with user-friendly electronical devices and a stiff competition between manufacturers are among the main reasons for decreasing the life span of such devices, and subsequently end up as an obsolete waste product. Rapid industrialization and urbanization have also caused many environmental problems, e.g. heavy metal contamination. Silver is one of the precious metals with exceptionally high industrial applications, which makes it an area of research of high interest. Demand for silver continues to grow with progress in the industrialized world, while the world reserves of high-quality silver ores are declining. Although, there are large stocks of low and lean quality silver ores still to be mined, the main goal of this article is to provide a simple, effective and eco-friendly method of silver recovery from e-waste, e.g. electrical circuit breakers using an electrochemical cell. After 20.75 days of the experiment, 1481.5 grams of silver contacts were processed with a final yield of $61.41 \%$ grams of silver dendrite crystals (99.9\% purity).
\end{abstract}

\section{Keywords}

Electrochemical recovery, electrolytic cell, silver, circuit breakers contacts

\section{INTRODUCTION}

With the rapid growth in the demand for new electronics and the ability to cater a wider public with accessibility reaching to every corner of the world involves stress created on the natural resources that need to be used in manufacturing the electronics. This is evident from the exponential raise of prices of some of the metals that are used in the electronic industry (Graedel et al., 2015). In recent years, a huge growth in the use of many information and communication 
technology products has been observed. E-waste has been a major segment of the waste produced in the past decades $[1,2]$. The world has generated approximately $53.6 \mathrm{Mt}$ of e-waste in 2019. In 2019, the formal documented collection and recycling was $9.3 \mathrm{Mt}$, thus $17.4 \%$ compared to the e-waste generated. The fate of $82.6 \%(44.3 \mathrm{Mt})$ of the e-waste generated in 2019 is unclear, and its whereabouts and the environmental impact varies across the different regions [3]. Although WEEE constitutes only $8 \%$ of municipal solid waste, the amount of metals present in it exceeds any other form of waste [4].

Silver is an extremely important metal because of its various useful properties and its economic value. In the recent years, natural resources of silver have been decreasing, the cost of silver productions has risen rapidly, and the market price of silver has undergone a decrease in spite of the increased numerous applications. Silver is used in four major areas, including the industrial, photography, jewellery and coin sectors.

The global demand for silver has been escalating progressively with the increasing consumption of electronic and electrical equipment (EEE) $[5,6]$.

Global silver demand in all four major areas reached $30.848 \mathrm{kt}$ in 2019 , while the supply reached $32.893 \mathrm{kt}$ with the highest long-term demand achieved in industry (15.891 kt), which also includes electronics and IT sector [7].

Table 1 shows the development of global silver demand during the years $2011-2019$ and the corresponding sector.

Table 1 Development of global silver demand by sectors (2011 - 2019) [7]

\begin{tabular}{l|ccccccccc} 
METRIC TONES & 2011 & 2012 & 2013 & 2014 & 2015 & 2016 & 2017 & 2018 & 2019 \\
INDUSTRIAL & 15804 & 14012 & 14332 & 13984 & 14189 & 15250 & 16087 & 15909 & 15891 \\
$\quad$...of which & 2127 & 1711 & 1571 & 1505 & 1683 & 2914 & 3166 & 2877 & 3070 \\
photovoltaics & & & & & & & \\
PHOTOGRAPHY & 1916 & 1633 & 1425 & 1356 & 1281 & 1176 & 1092 & 1064 & 1048 \\
JEWELLERY & 5045 & 4952 & 5819 & 6018 & 6302 & 5885 & 6106 & 6317 & 6261 \\
SILVERWARE & 1291 & 1247 & 1421 & 1630 & 1760 & 1627 & 1795 & 2034 & 1860 \\
NET PHYSICAL & 8460 & 7490 & 9334 & 8790 & 9654 & 6653 & 4858 & 5154 & 5788 \\
INVESTMENT & 32515 & 30590 & 33246 & 31775 & 33187 & 30963 & 30005 & 30739 & 30848 \\
TOTAL & & & & & & & & &
\end{tabular}

The most silver is obtained from mine production $(26.019 \mathrm{kt})$, followed by recycling supply $(5.284 \mathrm{kt})$. Among industrial materials, the volume of silver recovered increased for the $5^{\text {th }}$ year in succession, by $2 \%$ to $3.125 \mathrm{kt}$ [7].

Silver-containing materials arise from diversity of sources, such as manganese silver ore, refractory antimony ore, silver sulphide concentrates, lead-zinc sulphide concentrates, mining wastewater, spent photography/radiography films, electronic and electrical materials, waste jewellery, silver wares, brazing alloys, catalyst, batteries, dental amalgam, orthopaedic materials, spent bleach-fixing photographic/radiographic solution, electroplating solution and metallurgical processing solution are available in many forms. Processing of such sources is therefore complicated. However, the basic processing technology is shown in Figure 1 [8]. 


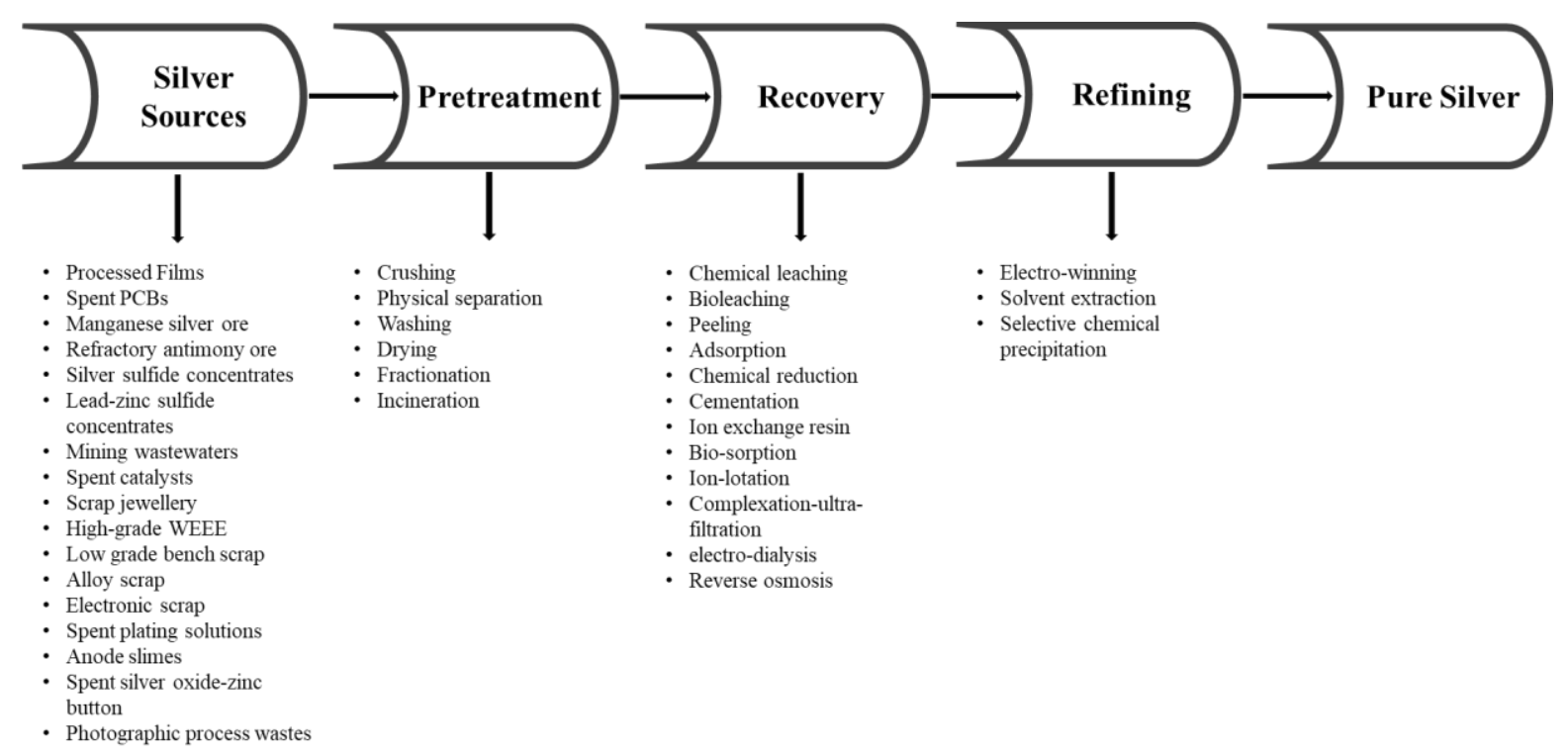

Figure 1 Silver recovery and recycling basic process flow sheet [8]

Tuncuk et al. [9] reported various treatment options based on conventional mechanical, physical, pyrometallurgical and hydrometallurgical processes for recovery of precious metals from waste of electric-electronic equipment (WEEE). A schematic flow sheet illustrating the processes available for recovery of precious metals from WEEE is shown in Figure 2.

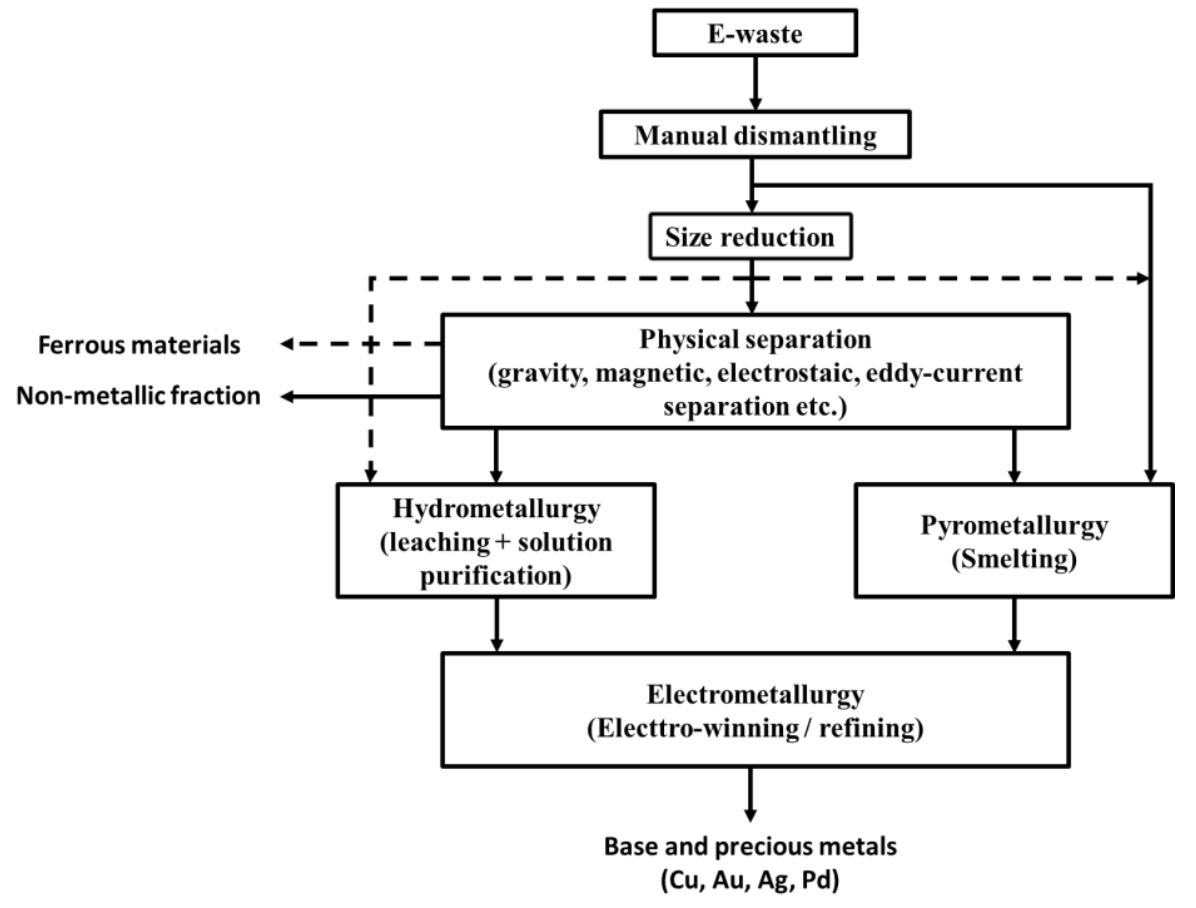

Figure 2 A schematic flowsheet showing the potential process option for recovery of metals from e-waste [9]

Pyrometallurgy and hydrometallurgy are the most common methods used for the recovery of metals from WEEE. However, pyrometallurgy requires high temperatures to extract the metals from WEEE which releases toxic gases that need to be cleaned before releasing into the environment [10]. On the other hand, hydrometallurgy does not require high temperatures, high operation costs, reduced environmental impact, and reasonable metal recovery rates. Hydrometallurgical treatment of WEEE typically uses mineral acids, such as $\mathrm{HCl}, \mathrm{H}_{2} \mathrm{SO}_{4}$, or $\mathrm{HNO}_{3}$ for the recovery of metals. Apart from that, it uses several reagents, such as cyanides, halide, thiosulfate or thiourea for the extraction of precious metals. 
Conventionally, in hydrometallurgy, mostly acids are utilized to selectively leach out the targeted metals. Then, through a series of refining processes as in electrorefining, precipitation, and cementation, the metals get further concentrated [11]. Leaching has proven to be more promising than pyrometallurgical processes, as it utilizes no external energy source and requires just the right solvents. The recovery rates are much higher compared to the pyrometallurgical processes [12].

Electrochemistry deals with the charge transfer at the interface between an electrically conductive material and an ionic conductor, as well as with the reactions within the electrolytes and the resulting equilibrium. Cathodic removal of heavy metals shows several benefits in terms of costs, safety and versatility. The equipment needed is only an electroplating bath, an insoluble anode and a suitable cathode. At the cathode, the metal ions are being reduced as shown:

$$
M n^{+}(a q)+n e^{-} \rightarrow M(s),
$$

where $\mathrm{M}=$ metal; $\mathrm{n}=$ valence of the metal. There are various competing reactions at the cathode, while the most common reaction is when the $\mathrm{H}^{+}$ions are being reduced to hydrogen gas.

$$
H^{+}(a q)+e^{-} \rightarrow 1 / 2 H_{2}(g) .
$$

Although the metal to be recovered will be deposited at the cathode, careful selection of the anode is needed to ensure that it will be inert in the electrolyte. Besides recovering metals in their metallic form, the electrochemical treatment of metal ion pollutants has several advantages: (1) no extra chemical reagents required; (2) no sludge production; (3) high selectivity; (4) and low operating cost [13]. However, there are certain disadvantages: the deposition rate and the composition of the solution in some cases can cause production of dendrites and loose or spongy deposits; and interference from the hydrogen evolution reaction or from dioxygen reduction has to be minimized [14].

In this study, a direct electrochemical method for silver recovery was used without any pyrometallurgy and hydrometallurgy steps needed. The aim was to use electrolysis of silver, as a well-stablished method for silver recovery to determine the recoverability of silver from materials without knowing the exact composition. Experimental parameters were investigated, including operation time, concentration of electrolyte and recoverability of silver contacts.

\section{MATERIALS AND METHODOLOGY OF EXPERIMENT}

A random selection of different contacts from circuit breakers $(\mathrm{CB})$ were selected for this study. The metal contents in CB vary from make to make and model to model, so a sufficient amount was prepared. In total, $1481.5 \mathrm{~g}$ of CB contacts were acquired by disassembly and desoldering the CB. The exact composition of the contacts was not determined; however the CB contacts of this type are usually made of various silver alloys containing mainly cadmium oxides, copper and nickel in different ratios [15]. Purity of the silver crystals was determined by an XRF gun to be $99.9 \%$. To construct the electrochemical cell, a stainless-steel hemisphere was filled with 3.51 of electrolyte at a concentration of $0.1386 \mathrm{~g} \cdot \mathrm{ml}^{-1}$. For the preparation of electrolyte, $99 \%$ pure silver was purchased from a silver dealer, and it was dissolved in a nitric acid (CentralChem s.r.o.) to produce silver nitrate. A stainless steel hemisphere was used as a cathode, while the anode was placed in the centre of the hemisphere into a plastic perforated sample (CB contacts) holder. Power supply (BK PRECISION 1696) attached to the cell provided a steady supply of voltage and current $(3.7 \mathrm{~V}, 1 \mathrm{~A})$. The operating parameters were set up according to the previous studies $[16,17]$. The diagram of electrochemical cell is shown in Figure 3. 

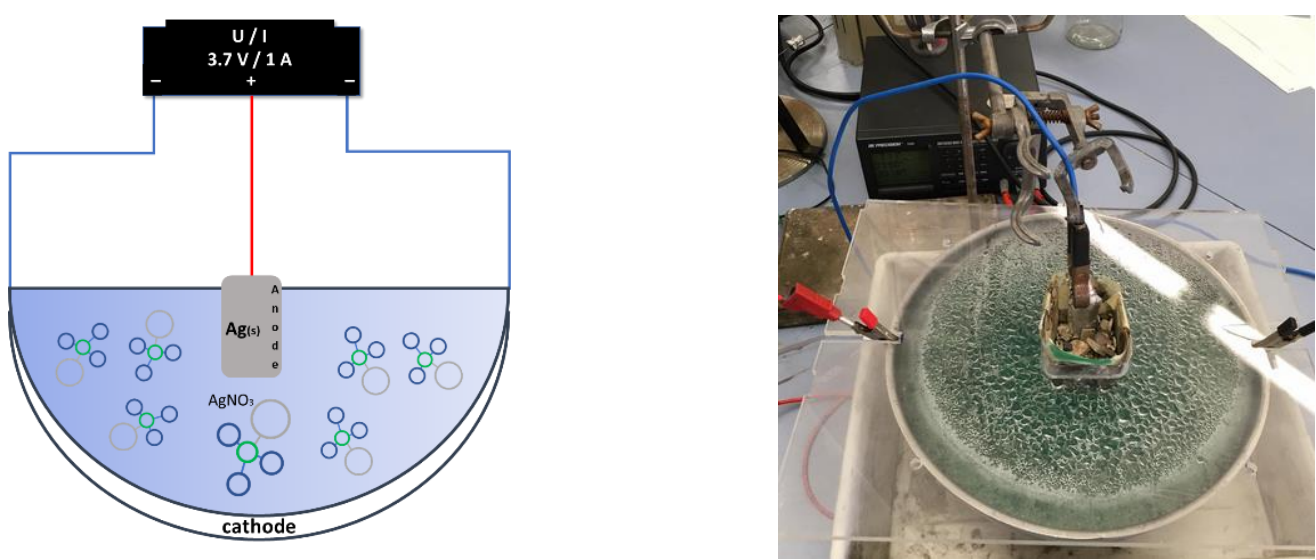

Figure 3 Diagram of electrochemical cell and electrochemical cell during experiment

In the experiment, a volume of solution used in the bath was fixed at 3.51 . The initial $\mathrm{pH}$ was adjusted to 1.45 (measured with WTW 340i multimeter) by using a $65 \%$ nitric acid. Temperature of the electrolyte was changed only by the passing current, thus it was not monitored. Silver does not dissolve in dilute $\mathrm{HCl}$ at the room temperature under moderate conditions, but it readily dissolves in dilute or concentrated $\mathrm{HNO}_{3}$ to yield a silver nitrate solution [18]. The following reactions (2) and (3) take place [19]:

$$
\begin{gathered}
3 \mathrm{Ag}^{0}+4 \mathrm{HNO}_{3(\mathrm{aq})} \rightarrow 3 \mathrm{AgNO}_{3(\mathrm{aq})}+\mathrm{NO}_{(\mathrm{g})}+2 \mathrm{H}_{2} \mathrm{O}_{(\mathrm{l})} \\
\mathrm{Ag}_{2} \mathrm{O}_{(\mathrm{s})}+2 \mathrm{HNO}_{3(\mathrm{aq})} \rightarrow 2 \mathrm{AgNO}_{3(\mathrm{aq})}+\mathrm{H}_{2} \mathrm{O}_{(\mathrm{l})}
\end{gathered}
$$

The anode and the cathode were cleaned thoroughly and stored in distilled water before use. The distance between the electrodes was $13 \mathrm{~cm}$. Anode area was $130 \mathrm{~cm}^{2}$ with the constant cathode current density maintained at $7.69 \mathrm{~mA} \cdot \mathrm{cm}^{-2}$ for all the experiments. Active area of the cathode (steel hemisphere) was approximately $1000 \mathrm{~cm}^{2}$. Ambient temperature during the experiment was $19-21{ }^{\circ} \mathrm{C}$, at the standard atmospheric pressure and humidity. Samples of $10 \mathrm{ml}$ of electrolyte were taken after 162, 330 and 498 hours from the beginning of the experiment to determine the concentration of $\mathrm{Ag}^{+}$in the electrolyte.

\section{RESULTS AND DISCUSSION}

Silver ions recovery from solution by the use of direct current is known as electro-winning. The ions in the solution are relocated to the cathode to form a metallic deposit [20].

The procedure outlined in this paper can be used to recover almost all of the silver present in the relay contacts. After 20.75 days of the experiment, the final yield of pure silver dendrite crystals was 1415.51 grams. Similar structure and purity of the crystals were reported by $[21,22]$. The dendritic Ag crystals formed during the experiment are shown in Figure 4.
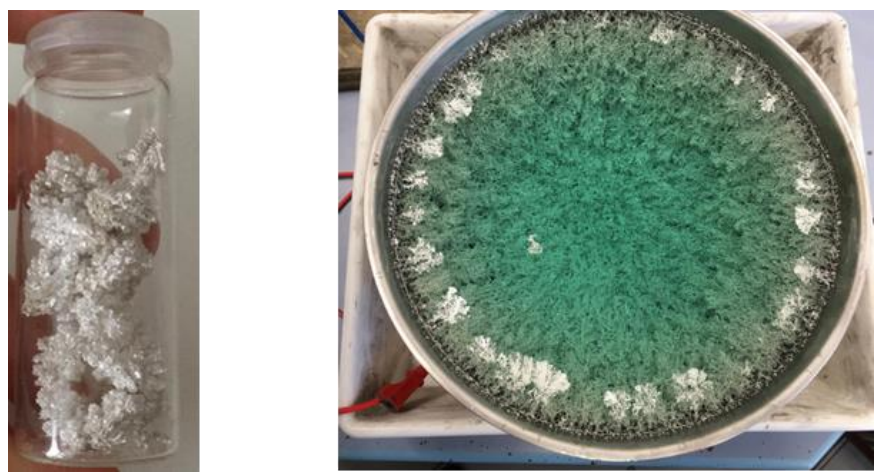

Figure 4 Dendritic Ag crystals formed on the cathode 
However, the final weight of the crystals has to be calculated from following equation:

$$
\text { Yield }_{A g}=\left(\frac{w_{t}-\left(w_{a}+w_{e l .}+\left(w_{0 e l .}-w_{1 e l .}\right)\right.}{w_{c}}\right) \times 100
$$

where $w_{t}$ is the total weight of relay contacts, $w_{a}$ is the weight of anode residues (unprocessed materials), $w_{e l}$ is the weight of dissolved anode, $w_{0 e l}$ is the weight of Ag dissolved in electrolyte at the start of the experiment, $w_{1 e l}$ is the weight of $\mathrm{Ag}$ dissolved in electrolyte at the end of the experiment and $w_{c}$ is the weight of Ag crystals. After acquiring all of the necessary parameters, the recoverable yield of $\mathrm{Ag}$ from the tested $\mathrm{CB}$ contacts was calculated to be $61.41 \mathrm{wt} \%$ (of pure Ag). Impurities dissolved in electrolyte (mixture of copper and nickel) were cemented out by an iron rod and yielded $23.4 \mathrm{wt} \%$. The resulting acidic solution was neutralised, evaporated and subsequently stored for further processing. The undissolved cadmium oxides (15.5 wt \%) were captured in the sample holder in the form of dark metallic sludge.

The current efficiency was calculated out from:

$$
c_{i}=m_{a} /\left(\frac{M}{n \times F} \times i \times t\right) \times 100,
$$

where $c_{i}$ is current efficiency, $m_{a}$ is actual mass of deposited silver, $M$ is atomic weight of silver, $n$ is oxidation state and $\mathrm{F}$ is Faraday constant. The current efficiency reached $45 \%$.

Throughout the experiment, the concentration of Ag in electrolyte was closely monitored. The initial height of the electrolyte level was noted, and the $10 \mathrm{ml}$ samples of the electrolyte were taken during the experiment to determine its concentration by potentiometric titration with a standard solution of $\mathrm{NaCl}$ using $\mathrm{Ag} / \mathrm{AgCl}$ and a saturated calomel electrode as an indicator electrode and a reference electrode, respectively. In total, four measurements were conducted, each after approximately seven days from the beginning of the cell operation time. As shown in graph in Figure 5, dependence of the Ag concentration in electrolyte on operation time was linear.

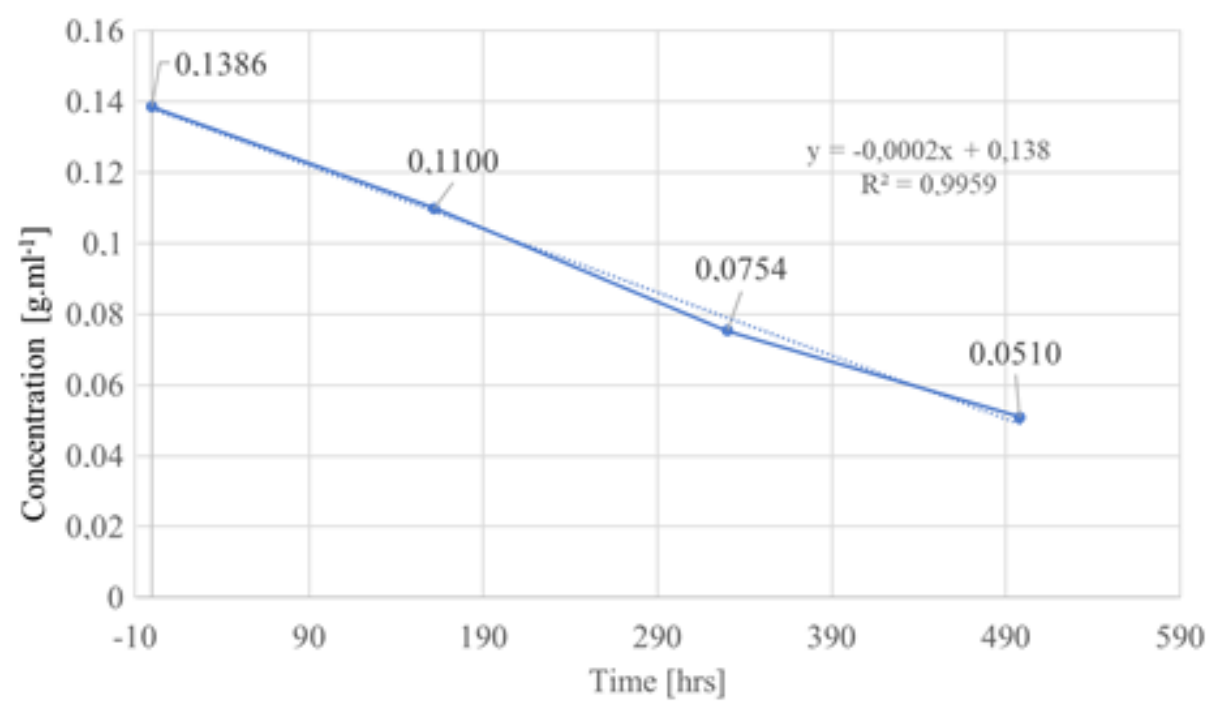

Figure 5 Change of Ag concentration in electrolyte dependent on operation time

In a different study [23], it was shown that the resulting solution (selective silver electroseparation from ammoniacal thiosulphate) recycled from leaching solutions back to the leach 
stage, reached similar performance to those produced by the fresh solution, because it has not significantly altered the composition, by the electro-separation process.

Electrowinning is one of the many techniques used for the recovery of valuable metals [24-26]. The precious metals recovered as anodic slimes in an electrochemical enhanced cell were predominantly recovered, and rarely required further electrorefining [26-29].

According to [14], it is desirable to have a model to describe the metal deposition recovery process as a function of operational parameters, such as time. In their study, the experimental parameters were investigated, including operation time, initial concentration, presence of organic substances, and ionic strength. The competitiveness of metal ions for electrolytic recovery was also studied.

Olutoye and Alhamdu [30] used an electrolytic method to separate silver metal from photolaboratory wastewater. The obtained silver metal attached as a chain onto the surface of a circular stainless steel material (cathode) during the setup similar to our study. It was revealed that the amount of recovered metal increased with the current applied as the time progressed with its peak at $0.6 \mathrm{~A}$ in the time range of $0.25-1.0 \mathrm{~h}$.

Gromov et al. [31] studied electrolysis of silver in $84-95 \mathrm{wt} \%$ sulfuric acid with addition of $40 \mathrm{~g} .1^{-1}$ of silver sulphate at electrolyte temperature of $40{ }^{\circ} \mathrm{C}$. They performed a semicommercial tests of the method for electrochemical recovery of silver from silver coatings on copper, brass, aluminium, and steel. Metallic silver with 99.9 wt \% purity was obtained with the average recovery degree of $99.0 \%$.

\section{CONCLUSION}

In this study, a direct electrochemical method where silver ions were relocated to the cathode to form a metallic deposit for silver recovery was used without any pyrometallurgy and hydrometallurgy steps needed. Recoverability of silver from CB contacts of unknown composition was investigated. During the experiment, the concentration of silver nitrate in electrolyte was monitored. This method can be used to recover almost all of the silver present in the anode basket. After 20.75 days of the experiment, the final yield of pure silver dendrite crystals was 1415.51 grams. However, from the final weight of the crystals, weight of other contributors (e.g. unprocessed samples, weight of dissolved anode, weight of Ag dissolved in the electrolyte, etc.) had to be subtracted and the recoverable yield of Ag from circuit breakers contacts was calculated to be $61.41 \%$ of pure Ag. Purity of the resulting silver crystals was determined by an XRF gun to be $99.9 \%$. Advantages of this procedure are: no extra chemical reagents needed, small amount of waste produced, low operational costs, high purity of the obtained metals. There are, however, also certain disadvantages, such as a relatively slow deposition rate, and the composition of the solution in some cases can cause production of dendrites or loose and spongy deposits. To further enhance the efficiency and other parameters of this setup, it is necessary to continue this research.

\section{Acknowledgement}

This contribution was supported by the Institutional project of FiTraW of STU MTF No. 1617.

\section{References}

[1] WIDMER, R., OSWALD-KRAPF, H., SINHA-KHETRIWAL, D., SCHNELLMANN, M., BÖNI, H. 2005. Global perspectives on e-waste. Environmental Impact Assessment Review, 25(5), 436458.

[2] BEHNAMFARD, A., SALARIRAD, M.M., VEGLIO, F. 2013. Process development for recovery of copper and precious metals from waste printed circuit boards with emphasize on palladium and gold leaching and precipitation. Waste Management, 33(11), 2354-2363. 
[3] FORTI, V., BALDÉ, C., KUEHR R., BEL, G. 2020. The Global E-waste Monitor 2020. Quantities, flows, and the circular economy potential. UNU/UNITAR and ITU, 2020. ISBN: 97892-808-9114-0

[4] HOSSAIN M.S., AL-HAMADANI S., RAHMAN M.T. E-waste: A Challenge for Sustainable Development. Journal of health \& pollution, 5(9), 3-11. https://doi.org/10.5696/2156-9614-5-9.3.

[5] VATS, M., SINGH, S. 2015. Assessment of gold and silver in assorted mobile phone printed circuit boards (PCBs): Original article. Waste Management, 45, 280-288. https://doi.org/10.1016/j.wasman.2015.06.002

[6] CAYUMIL, R., KHANNA, R., RAJARAO, R., IKRAM-UL-HAQ, M., MUKHERJEE, P.S., SAHAJWALLA, V. 2016. Environmental Impact of Processing Electronic Waste - Key Issues and Challenges. E-Waste in Transition - From Pollution to Resource. IntechOpen, 2016. ISBN: 978-953-51-6660-3

[7] NEWMAN, P., et al. 2020 World Silver Survey 2020. The Silver Institute and Metals Focus, 2020. ISBN: 978-1-9162526-5-3

[8] SYED, S. 2016. Silver recovery aqueous techniques from diverse sources: Hydrometallurgy in recycling. Waste management, 50, 234-256. https://doi.org/10.1016/j.wasman.2016.02.006.

[9] TUNCUK, A., STAZI, V., AKCIL, A., YAZICI, E.Y., DEVECI, H. 2012. Aqueous metal recovery techniques from e-scrap: Hydrometallurgy in recycling. Minerals Engineering, 25(1), 28-37. https://doi.org/10.1016/j.mineng.2011.09.019.

[10] WANG, H., ZHANG, S., LI, B., PAN, D., WU, Y., ZUO, T. 2017. Recovery of waste printed circuit boards through pyrometallurgical processing: A review. Resources, Conservation and Recycling, 126, 209-218. https://doi.org/10.1016/j.resconrec.2017.08.001.

[11] ABDELBASIR, S.M., HASSAN, S.S.M., KAMEL, A.H., EL-NASR, R.S. 2018. Status of electronic waste recycling techniques: a review. Environmental Science and Pollution Research, 25(17), 16533-16547. https://doi.org/10.1007/s11356-018-2136-6.

[12] ASHIQ, A., COORAY, A., SRIVATSA, S.CH., VITHANAGE, M. 2020. Electrochemical enhanced metal extraction from E-waste. In: Handbook of Electronic Waste Management. Elsevier, 2020. 119-139. ISBN: 978-0-12-817030-4

[13] CHEN, J.P. 2013. Decontamination of Heavy Metals Processes, Mechanisms, and Applications. $1^{\text {st }}$ ed. CRC Press, 2013. 454 p. ISBN 9781439816677

[14] CHEN, J.P., LIM, L.L. 2005. Recovery of precious metals by an electrochemical deposition method. Chemosphere, 60(10), 1384-1392. https://doi.org/10.1016/j.chemosphere.2005.02.001.

[15] SINCVLAIR, I. 2000. Passive Components for Circuit Design. Elsevier. ISBN: 978-0-7506-49339

[16] MAURELL-LOPEZ, A.K., FRIEDRICH, B., KOCH, W. 2017. Challenges in the Electrolytic Refining of Silver-Influencing the Co-deposition Through Parameter Control. In: Rare Metal Technology, 103-117. https://doi.org/10.1007/978-3-319-51085-9 11

[17] AJI, A.T., AROMAA, J., LUNDSTRÖM, M. 2020. The Optimum Electrolyte Parameters in the Application of High Current Density Silver Electrorefining. Metals, 10(12), 1596. https://doi.org/10.3390/met10121596

[18] HOLLOWAY, P.C., MERRIAM, K.P., ETSELL, T.H. 2004. Nitric acid leaching of silver sulphide precipitates. Hydrometallurgy, 74(3-4), 213-220. https://doi.org/10.1016/j.hydromet.2004.05.003.

[19] VOGEL, A.I., SVEHLA, G. 1987. Vogel's qualitative inorganic analysis. $6^{\text {th }}$ ed. Harlow, Essex, England : Longman Scientific \& Technical ; New York : Wiley, 1987. 310p.

[20] ABBRUZZESE, C., FORNARI, P., MASSIDDA, R.,VEGLIÒ, F.,UBALDINI, S. 1995. Thiosulphate leaching for gold hydrometallurgy. Hydrometallurgy, 39(1-3), 265-276. https://doi.org/10.1016/0304-386X(95)00035-F.

[21] AKTAS, S. 2010. Silver recovery from spent silver oxide button cells. Hydrometallurgy, 104(1), 106-111. https://doi.org/10.1016/j.hydromet.2010.05.004.

[22] ABDEL-AAL, E.A., FARGHALY, F.E. 2007. Preparation of silver powders in micron size from used photographic films via leaching-cementation technique. Powder Technology, 178(1), 51-55. https://doi.org/10.1016/j.powtec.2007.03.041.

[23] ALONSO, A.R., LAPIDUS, G.T., GONZÁLEZ, I. 2008. Selective silver electroseparation from ammoniacal thiosulfate leaching solutions using a rotating cylinder electrode reactor (RCE). Hydrometallurgy, 92(3-4), 115-123. https://doi.org/10.1016/j.hydromet.2008.02.001. 
[24] KIM, E-Y., KIM, M-S., LEE, J-CH., PANDEY, B.D. 2011. Selective recovery of gold from waste mobile phone PCBs by hydrometallurgical process. Journal of Hazardous Materials, 198, 206-215. https://doi.org/10.1016/j.jhazmat.2011.10.034.

[25] YI, Q., FAN, R., XIE, F.,MIN, H., ZHANG, Q., LUO, Z. 2016. Selective Recovery of Au(III) and Pd(II) from Waste PCBs Using Ethylenediamine Modified Persimmon Tannin Adsorbent. Procedia Environmental Sciences, 31, 185-194. https://doi.org/10.1016/j.proenv.2016.02.025.

[26] YONG, Y.S., LIM, Y.A., ILANKOON, I.M.S.K. 2019. An analysis of electronic waste management strategies and recycling operations in Malaysia: Challenges and future prospects. Journal of Cleaner Production, 224, 151-166. https://doi.org/10.1016/j.jclepro.2019.03.205.

[27] ALZATE, A., LÓPEZ, E., SERNA, C., GONZALEZ, O. 2017. Gold recovery from printed circuit boards by selective breaking of internal metallic bonds using activated persulfate solutions. Journal of Cleaner Production, 166, 1102-1112. https://doi.org/10.1016/j.jclepro.2017.08.124.

[28] ASHIQ, A., GUNARATHNE, V., VITHANAGE, M. 2019. Overview Scheme for Nickel Removal and Recovery from Wastes. In.: Nickel in Soils and Plants. CRC Press.

[29] MAKUEI, F.M., SENANAYAKE, G. 2018. Extraction of tellurium from lead and copper bearing feed materials and interim metallurgical products - A short review. Minerals Engineering, 115, 7987. https://doi.org/10.1016/j.mineng.2017.10.013.

[30] OLUTOYE, M., ALHAMDU, J.A. 2014. Electrochemical Separation of Metal Silver from Industrial Wastewater. Advances in Chemical Engineering and Science. 4, 396-400. doi: 10.4236/aces.2014.44043.

[31] GROMOV, O.G., KUZ'MIN, A.P., KUNSHINA, G.B. et al. 2004. Electrochemical Recovery of Silver from Secondary Raw Materials. Russian Journal of Applied Chemistry, 77, 62-66. https://doi.org/10.1023/B:RJAC.0000024577.90857.07.

\section{ORCID}

Igor Wachter 0000-0003-0691-0462

Tomáš Štefko 0000-0002-3975-6775 